\title{
9. Türkiye Tefsir Akademisyenleri Buluşması ve “Kur’an Nüzûlünün Mekke Dönemi Sempozyumu"
}

Ömer DiNÇ*

9. Türkiye Tefsir Akademisyenleri Buluşması 29 Haziran - 1 Temmuz 2012 tarihleri arasında Hitit Üniversitesi İlahiyat Fakültesi ev sahipliğinde Çorum'da yapıldı. Yaklaşık 150 'ye yakın akademisyenin katıldığı bu buluşma vesilesiyle geçen sene tertip edilen sempozyumun bir devamı niteliğinde olan "Kur'an Nüzûlünün Mekke Dönemi" sempozyumu gerçekleştirildi.

Sempozyum açllışından önce Tefsir akademisyenlerine Çorum müzesi gezdirilerek Çorum'un tarihi ve kültürü hakkında bilgi verildi. Cuma namazının ardından saat 14:30'da sempozyum açılışı gerçekleşti. Açılış programına, Vali Vekili, Belediye Başkanı, Hitit Üniversitesi Rektörü, Çorum Müftüsü, üniversitenin öğretim elemanları, öğrenciler ile Çorum halkı iştirak etti. Program Prof. Dr. Sadık Kılıç'ın Kur'an tilavetiyle başladı. Ardından sempozyum tertip heyeti adına bir konuşma yapan Hitit Üniversitesi Illahiyat Fakültesi Dekanı ve Tefsir Anabilim Dalı Başkanı Prof. Dr. Mesut Okumuş, sempozyumla alakalı olmak üzere şunları kaydetti: "Allah Resulü "Âlimler peygamberlerin vârisleridir" diye buyurmuştur. Biz tefsir akademisyenlerine yakışan da "âlim" vasfinın içeriğini doldurmaya çalışmak, Son Elçi'nin mesajına ve mirasına sahip çıkmak, kısacası mirasyedilik yapmamaktır. Temel İslam İlimlerinin temelini, dini esas ve özünü temsil eden tefsir ilminin biz uzmanlarına düşen birincil görev, Kur'an'dan ve Allah Resulü'nün örnek hayatından alacağımız ders ve ilhamla İslam'ı, çağımız insanının idrakine sunmaktır." Mesut Okumuş'un konuşmasının ardından Hitit Üniversitesi Rektörü Prof. Dr. Reha Metin Alkan ve Çorum Belediye Başkanı Muzaffer Külcü de bu sempozyumun önemine ve anlamına dikkat çektiler.

Sempozyum aç1lış konuşmalarının akabinde açılış oturumuna geçildi. Prof. Dr. Sadrettin Gümüş başkanlığındaki oturumda Prof. Dr. Zeki Duman, “Vah-

* $\quad$ Ar. Gör., Hitit Üniversitesi İlahiyat Fakültesi 
yin Penceresinden Mekke Dönemi" başlıklı tebliğini sundu. Zeki Duman, Mekke döneminde nâzil olan "Beled" suresinin mealini ve tefsirini yapmak suretiyle Kur'an'ın o dönemde Mekke'yi nasıl tasvir ettiği üzerinde durdu. İkinci tebliğin sahibi Prof. Dr. Hasan Elik ise "Kur'an Nüzûlünün Hz. Peygamber' in Sireti İle İlişkisi" ve Atatürk Üniversitesi İlahiyat Fakültesi Dekanı Prof. Dr. Nasrullah Hacımüftüoğlu ise "Mekkî Sure ve Ayetlerde Tahaddî ve Belagat" isimli tebliğlerini sunarak Mekke dönemine dair bir girizgâh oluşturdular.

2. oturumun başkanlığını Ankara Üniversitesi İlahiyat Fakültesi Öğretim üyesi Prof. Dr. Salih Akdemir yaptı. Bu oturumda Prof. Dr. Fethi Ahmet Polat “Kur'an'ın Mekki Surelerinde Müşriklere Yönelik Eleştirel Dil”, Prof. Dr. Sadrettin Gümüş “Kur'ân'ın Arabistan'da ve Arapça Olarak İndirilmesinin Sebep ve Hikmetleri”, Prof. Dr. Remzi Kaya “Kur'an'ın Mekki Surelerinde Ehl-i Kitab" başlıklı tebliğlerini sunarlarken Prof. Dr. Sait Şimşek ve Prof. Dr. İshak Yazıcı da bu tebliğlerin müzakerelerini yaptılar. İlmî anlamda yoğun geçen günün akşamında ise Yrd. Doç. Dr. Ubeydullah Sezikli ve ekibi, katılımcı akademisyenlere ve Çorum halkına yönelik bir Tasavvuf Musikisi Konseri icra ettiler.

Sempozyumun ikinci gününde 3. oturumun başkanlığını Ankara Üniversitesi İlahiyat Fakültesi Öğretim Üyesi Prof. Dr. Halis Albayrak yaptı. Prof. Dr. İdris Şengül, “Mekke Dönemi'nde Kur'an'1 Kerim'in Okunması, Ezberlenmesi ve Yazıyla Kaydedilmesi" konulu tebliğini sunarken Prof. Dr. Veysel Güllüce de konunun müzakerecisi oldu. Doç. Dr. Selim Türcan, “Tefsirde Bir Yöntem Esası Olarak Kur'an Kronolojisi Meselesi" konulu tebliğini sunarken müzakerecisi ise Prof. Dr. Mehmet Akif Koç oldu. Son konuşmacı ise "Hartwig Hirschfeld'in Ayetleri Tarihlendirme Çabaları" adlı tebliği ile Yrd. Doç. Dr. Davut Şahin olurken müzakeresini Doç. Dr. Bilal Gökkır yaptı.

4. oturumda oturum başkanı Atatürk Üniversitesi İlahiyat Fakültesinden Prof. Dr. Sadık Kılıç'tı. İlk tebliğ sahibi Yrd. Doç. Dr. Hüseyin Çelik'in “Kur'an'ın Mekke Toplumunda Var Olan Birtakım Yanlış İnanç ve Davranışları Islah Etmesi" başlıklı tebliğini sunarken müzakerecisi Prof. Dr. Muhammed Aydın'dı. Ardından Yrd. Doç. Dr. Zeki Tan, "Mekkî Ayetlerde Kadın Tasavvuru İnşasının Ahlakî Zemini" isimli tebliğini sundu ve müzakeresini Yrd. Doç. Dr. Hatice Şahin yaptı. Oturumun son konuşmacısı olan Doç. Dr. Nurettin Turgay da "Mekkî Ayetlerde İnsan Eşitliği ve Sosyal Adalet Merkezli Temalar" tebliğini sundu ve onun müzakeresi de Prof. Dr. Ali Rıza Gül tarafından yapıldı. Dinleyicilerin soru ve katkıları alındı.

5. oturumda oturum başkanı Dokuz Eylül Üniversitesi İlahiyat Fakültesi 
Dekanı Prof. Dr. Ömer Dumlu'ydu. Bu oturumun ilk tebliğcisi olan Prof. Dr. İsmail Çalışkan “Kur' an Vahyinin İlk On İki Yılı: Kelimeler ve Kavramlarla Bir Zihniyet İnşası" adlı tebliğini sunarken müzakeresi ise Prof. Dr. Mehmet Paçacı tarafından yapıldı. İkinci tebliğ sahibi Prof. Dr. Ali Akpınar ise "Mekki Sure ve Ayetlerde Müminlere Yönelik Hitaplar" başlıklı bildirisini sundu ve Prof. Dr. Abdülhamit Birısık ise bu tebliği özet bir şekilde müzakere etti. Bu oturumun son tebliğini ise ev sahibi olan Prof. Dr. Mesut Okumuş sundu. Tebliğ konusu ise "Mekki Surelerde Hz. Peygamber'e Yönelik Hitaplar" şeklinde idi. Bu tebliğin müzakeresi de Prof. Dr. Hüseyin Yaşar tarafından yapıldı.

6. oturumda oturum başkanı Erciyes Üniversitesinden Prof. Dr. Lütfullah Cebeci oldu. Hitit Üniversitesi İlahiyat Fakültesi'nden Yrd. Doç. Dr. Ömer Başkan "Yetim Kavramı Bağlamında Mekki Ayetlerde Toplumun Zayıf Unsurlarına Yönelik Eleştirel Koruyucu Dil" başlıklı oturumun ilk tebliğini sunarken müzakeresi Doç. Dr. Necmettin Gökkır tarafından yapıldı. İkinci tebliğin sahibi ise Yrd. Doç. Dr. Mustafa Güven "Mekki Surelerde Cahili Arap Aklına Yöneltilen Eleştiriler" isimli tebliğini arz etti. Müzakeresi Prof. Dr. Mevlüt Güngör tarafından yapıldı. 6. Oturumun son bildiri sahibi Bayram Ayhan ise "Kadir Gecesinin Tespiti Sorunu" tebliğinin sunumunu yaptı ve müzakeresi de Doç. Dr. Mehmet Ünal tarafından gerçekleştirildi.

30 Haziran 2012 Cumartesi günü 4. oturumla eş zamanlı olarak Tefsir Anabilim Dalı Başkanları tarafından Prof. Dr. Celal Kırca başkanlığında "Tefsir Anabilim Dalı Yeterlilik Ölçütlerinin Tespiti" konulu bir çalıştay gerçekleşti. Bu çalıştayda Tefsir Anabilim Dalıyla alakalı pek çok karara imza atıldı. Bu çalıştayda alınan kararlar önümüzdeki dönemde dekanlar toplantısına sunulacak ve ardından İlahiyat Fakültelerinin müfredatının gözden geçirilmesi sürecinde esas teşkil edecektir.

Sempozyumun sonunda değerlendirme oturumunda oturum başkanlığını Atatürk Üniversitesi İlahiyat Fakültesi Dekanı Prof. Dr. Nasrullah Hacımüftüoğlu üstlendi. Prof. Dr. Salih Akdemir, Prof. Dr. Sadrettin Gümüş, Prof. Dr. Halis Albayrak, Prof. Dr. Sadık Kılıç, Prof. Dr. İdris Şengül, Prof. Dr. Celal Kırca ve Prof. Dr. Mesut Okumuş sempozyumun genel bir değerlendirmesini yaparak görüş ve tekliflerini sundular. Yine bu oturumda söz almak isteyen hocalar sempozyumla ilgili görüş ve değerlendirmelerini dile getirdiler. Değerlendirme oturumunda çalıştayda aldıkları kararları Tefsir Akademisyenleri ile paylaştılar.

Değerlendirme oturumunda Tefsir akademisyenleri, böyle güzel bir organizasyon içinde bulunduklarından, bu toplantının her anlamda beklentilerinin 
çok üzerinde gerçekleştiğini ifade ettiler. Çorum'un sergilediği misafirperverliğinden ve yaptığı ev sahipliğinden çok memnun kaldıklarını defalarca dile getirdiler. Bu memnuniyetin oluşmasına vesile olan Çorum Belediye Başkanı Muzaffer Külcü'ye, Hitit Üniversitesi Rektörü Prof. Dr. Reha Metin Alkan'a ve Hitit Üniversitesi İlahiyat Fakültesi Dekanı Prof. Dr. Mesut Okumuş'a da her fırsatta teşekkürlerini bildirdiler.

Değerlendirme oturumunun ardından, Cumartesi akşam saat 21:30'da Mimar Sinan Cuma Pazarı'nda, Tefsir hocaları tarafından Çorum Belediyesinin katkılarıyla halka bir Kur'an ziyafeti tertip edildi. Prof. Dr. Salim Ögüut anısına gerçekleştirilen bu programa, Belediye Başkanı, Hitit Üniversitesi İlahiyat Fakültesi Dekanı, diğer İlahiyat Fakültelerinin dekanları, Salim Öğüt Hocanın eşi, Tefsir Akademisyenleri ve Çorum halkından da yaklaşık 4000 kişi iştirak etti. Programın açılışında konuşan İlahiyat Fakültesinin Dekanı Prof. Dr. Mesut Okumuş, Kur'an'ın yaşanması ve tefsiri kadar okunmasının da bir ibadet olduğunu vurgulayarak bu Kur'an ziyafetinin anlamına ve önemine dikkat çekti. Ayrıca Okumuş, Türkiye'nin değişik İlahiyat Fakültelerine mensup tefsir akademisyenlerinin muhtelif kıraat ve vücuh tarzlarından örnekler sunacağ Kur'an ziyafeti ile Çorumlular için çok ayrı bir yeri olan Prof. Dr. Salim Öğüt'ü anacaklarını ifade etti. Programı yöneten Prof. Dr. Remzi Kaya ile birlikte Kur'an tilavet eden karîler arasında Prof. Dr. M. Kemal Atik, Prof. Dr. Sadık Kılıç, Prof. Dr. Mehmet Akif Koç, Doç. Dr. Yaşar Kurt, Yrd. Doç. Dr. Ömer Aslan, Yrd. Doç. Dr. Ömer Başkan, Yrd. Doç. Dr. Yusuf Alemdar, Öğr. Gör. İbrahim Uludaş, Öğr. Gör. Enes Saka, Öğr. Gör. Bilal Atik ve Sungurlu Merkez Cami Müezzini Yaşar Zorlu yer aldı. Çorum halkının büyük bir ilgi ile dinlediği Kur'an ziyafeti, Çorum Müftüsü Mehmet Âşık tarafından yapılan dua ile sona erdi.

Programın son gününde ise Tefsir Akademisyenlerine Çorum'un tarihi yerleri olan Alacahöyük ve Boğazkale gezdirildi. Hem bu geziden hem de programın bu kadar güzel geçmesinden dolayı çok mutlu olduklarını belirten Tefsir Akademisyenleri, bu güzel programa ev sahipliği yapan Çorum'a, Çorum halkına, Çorum Belediyesine, Hitit Üniversitesine, İlahiyat Fakültesine ve bu sempozyumu düzenleyen ekibe minnettar olduklarını, büyük bir memnuniyet ve mutluluk içinde ayrılacaklarını ifade ederek, bu programın unutulmayacağını dile getirdiler. 